\title{
Effectiveness of Digital Learning in Primary Schools at COVID-19
}

\author{
Jonni Siahaan $^{1}$, Rif'iy Qomarrullah ${ }^{2}$, I Putu Eka Wiajaya Putra ${ }^{3}$ \\ \{jonni.siahaan@gmail.com ${ }^{1}$, qommarrifqi77@gmail.com ${ }^{2}$, ekawijayap@gmail.com ${ }^{3}$ \} \\ Cenderawasih University, Jayapura Papua, Indonesia ${ }^{123}$
}

\begin{abstract}
This type of research is quantitative, the subjects of this study involved 31 5th grade elementary school students. The targets of the research target are health science education teaching materials. This study uses an instrument rubric assessment of student activity and learning response questionnaire by involving parents in its implementation. After conducting this research for one month, and checking through video recordings of student activities with parents collected during the activity. The results of data analysis in this study show that from the formative class evaluation above the average and from the learning data process and product results graphically each learning has increased. This shows if digital learning is accepted and understood by students. Therefore, digital media was very helpful during the Covid-19 pandemic outbreak disaster. However, in the future it is necessary to collaborate with the world of education and assist parental involvement in digital-based learning.
\end{abstract}

Keywords: digital learning, students, Covid-19

\section{Introduction}

Developing civilization on the basis of pluralism is a spirit in the culture of the archipelago (nusantara). Therefore, the various character of education in Indonesia includes three main elements, namely: first, "ing ngarsa sung tuladha" (before becoming a role model); second, "ing madya mangun karsa" (in the middle of the example); and third, "tut wuri handayani" (giving freedom by monitoring). This educational ideology as outlined by Ki Hadjar Dewantara as a hero of national education[1] ${ }^{1}$.

Elementary school (SD) as part of the stages of basic education is the entrance to how the younger generation of civilization is formed. This period is then known as the most important period of knowledge transfer in the learning process. Children are trained to know the rows of letters and numbers, scientific didactic methodology recognizing reading and counting applies throughout the world. Education in turn cannot be separated from the curriculum. Indonesia itself with a diversity of cultures, ethnicities, religions, and races is unique in the application of teaching materials. The curriculum is a set of material list packages arranged in each subject[2] $]^{2}$. The objectives of 
the curriculum are 4 competencies: a. Spiritual; b. Social behavior; c. Knowledge; and D. Skills. The curriculum currently in effect in Indonesia is K-13 (curriculum in 2013. Furthermore, in the implementation of K-13 there are competency standards which are indicators of achievements in the teaching and learning process which are divided into two: a Basic competence (KD) $[3]^{3}$ : contains indicators of performance in general that are applied in the perspective of all subjects, and b. Core competence (KI): contains indicators of focus on achievement in each subject.

A phenomenon that occurs is that education in the era of disruption such as now makes teachers have to adapt to all technological advances, especially after the emergence of the Covid-19 pandemic epidemic throughout the world. Covid-19 or coronavirus disease 2019 is a disease caused by a new type of coronavirus, Sars-CoV-2, which was first reported in Wuhan China on December 31, 2019[4] $]^{4}$. Common symptoms caused by Covid-19 by people infected with this virus that will experience symptoms such as cough, flu, sore throat, shortness of breath, lethargy and fatigue even in some cases patients will experience pneumonia or lung problems. The incubation period of Covid-19 between the period of contracting the virus and the appearance of symptoms of the disease, is generally estimated to range from 1 to 14 days or can be around 15 days.

The impact arising from this outbreak in the industrial era 4.0 is the existence of a new order of life which then relies on digitizing the system. The field of education as also affected then transformed to conduct disruption of teaching methods by conducting online or digital-based educational learning $[5]^{5}$. This event marked a change in the behavior of educators and students in which digital learning which initially only became the main distraction in teaching methods in the classroom today amid the epidemic of the Covid-19 virus pandemic in 2020 became the main focus. Students scattered in 175,090 primary schools in Indonesia must be closed for a time limit that has not been determined until when the normal details $[6]^{6}$. The problem that arises is that people are not used to it, especially teachers, students and parents facing the current emergency medical situation. Pandemic Covid-19 has made 24,757,561 students, and $1,467,461$ elementary school teachers in Indonesia to carry out distance learning (PJJ) from their respective homes.

Based on research data from various sources in May 2020, specifically for the Papua Province region, the number affected by Covid-19 was 438,038 students and 16,023 teachers spread in 2,646 elementary schools. Geographically, Papua Province consists of 29 Regencies / Cities, with an area of 316,553.07 Km2 (square kilometers), or equivalent to 3 times the area of Java which covers 128,297 $\mathrm{Km}^{2}$. Papua's relatively unbalanced condition when compared to other provinces in Indonesia in terms of infrastructure and technological outreach is also a problem. But in the midst of existing limitations, teachers continue to strive to carry out distance learning. Based on this situation, the researcher was moved to do real work by making a break- 
through in digital learning in collaboration with grade 5 teachers of SDN Inpres Perumnas 1 Heram, Jayapura City. The teaching material provided is a combination of digital-based learning and material insertion which also touches on a healthy lifestyle and educates students and parents in order to overcome Covid-19 transmission.

As explained earlier, the implementation of KD and IC in elementary schools is using an integrated thematic concept, where in the implementation of learning in the classroom the teacher uses stories in one or two more interrelated themes between subjects. The integrated thematic, taught at grade level 1 to grade 6. Specifically, this study focuses on grade 5 grades in primary schools in which there is the theme of clean air for health. Researchers and teachers then formulate the media used and focus on the right material to be taught. Zoom and whattsap (WA) application media are then agreed upon by researchers and teachers to be used in the implementation of digital-based learning. Zoom is an application that is easy, inexpensive, does not require a device that is too difficult, and can load various kinds of people from all over the city of Jayapura. In addition, WA media was chosen because it can unite a variety of cellular telephone numbers in a group[7] ${ }^{7}$, coordination in the WA group becomes important to ensure the role of parents in mentoring students who participate in this learning activity.

Socially and culturally, another impact arising as a result of the emergence of Covid-19 for humans in the future is a change in new behavior or new life. Humans, viruses, and the digital world will co-exist well. Social isolation for a long period of time is not an effective solution. All sectors including the education sector are very beneficial in the presence of this kind of research. So in addition to the efforts that researchers have made, it is hoped that there will be other researches that are able to provide active solutions in an effort to bring an education sector that adapts to the disruption of the developing world.

\section{$2 \quad$ Method}

This research uses quantitative descriptive positivistic method, which reveals facts based on data according to the incident as it happened. Disclosure of facts is collected using numerical data (numbers) in answering problems for a phenomenon that appears at this time $[8]^{8}$. This study aims to find the magnitude of the relationship between the independent variables with the dependent variable in one research subject empirically. Based on the extent and scope of the study, a pre-experimental design with a one-shot case study pattern was chosen in the data collection process. The treatment in this study was given to grade 5 students at SDN (public elementary school) Inpres Perumnas 1 Heram, Jayapura City, Papua Province of Indonesia, who carried out learning from their homes during the Covid-19 pandemic. The main subject of this research is the thematic learning "clean air for health". There were 31 students involved as subjects in the study, consisting of: 17 boys and 14 girls. The implementation of this research is from March to April 2020. This study provides 
interaction between students, teachers, researchers, and parents, where the zoom application is used when face-to-face giving teaching material, and WA media contains instructions, and information and communication interactions between parents and teachers. Thematic integrated in this study is "clean air for health", and is divided into 3 segments, including: (1) Sub-theme one: the way the body processes clean air; (2) Sub-theme two: the importance of clean air for breathing; and (3) Sub-theme three: maintaining the health of human respiratory organs. This study uses two instruments, namely: (1) Formative Evaluations in Online Classes (FEOC); and (2) Rubric of student performance learning outcomes assessment.

This study uses descriptive statistical analysis techniques. This is done to describe the effectiveness of learning based on the criteria indicators that have been prepared. Descriptive statistics explain facts that occur based on data, then the findings that occur in research are translated into languages that provide justification. The following is the range of scores and categories in formative class evaluation: (1) $\geq 2.77$ (excellent); (2) 2.55-2.76 (good); (3) 2.34-2.57 (moderate); (4) 2.15-233 (poor); (5) $\leq 2,14$ (very poor) [30]. Next is the conversion score of the process components and student learning products: (1) 91-100 (excellent); (2) 76-90 (good); (3) 61-75


of the study used interpretations of learning analysis using a cluster of qualitative sentences in the form of: (1) $81 \%-100 \%$ (excellent); (2) 75\%-85\% (good); (3) 65\% $74 \%$ (moderate); (4) $55 \%-64 \%$ (poor); (5) <54\% (very poor) $[10]^{10}$.

\section{Results and Discussion}

The results represent exposure to the data that researchers have found and obtained from subjects, the description can be presented in the form of four data points as follows:

Based on the formative class evaluation data filling which aims to obtain student response data on the application of the learning model, this questionnaire contains several elements: results, volume, method, and cooperation. The first learning activities carried out on Monday 30 March 2020 obtained the following questionnaire data for students: (1) The results component consists of 3 questions with an average score range of 2.19; (2) Volition component consisting of 2 questions with an average range of scores is 2.58; (3) Component method which consists of 2 questions with a range of average scores is 2.34; and (4) Cooperation component consisting of 2 questions with an average range of scores is 2.47 . Overall average range of scores in the first learning is 2.37 , which means moderate;

The first learning activities that were held on Monday, April 6, 2020 obtained the following questionnaire data for students: (1) The results component consists of 3 questions with an average score range of 2.59; (2) Volition component consisting of 2 questions with an average range of scores is 2.58; (3) Component method which con- 
sists of 2 questions with a range of average scores is 2.60; and (4) Cooperation component consisting of 2 questions with an average range of scores is 2.58 . Overall the average range of scores in the first learning is 2.59 , which means included in the good category.

The first learning activities that were carried out on Monday, April 13, 2020 obtained the following questionnaire data for students: (1) The results component consists of 3 questions with an average score range of 2.84; (2) Volition component consisting of 2 questions with an average score range of 2.79; (3) Component method which consists of 2 questions with a range of average scores is 2.35; and (4) Cooperation component consisting of 2 questions with an average range of scores is 2.60 .

Table 1. Process and Product Learning Data

\begin{tabular}{llll}
\hline Activity & & Product & Category \\
\hline \multirow{3}{*}{1} & Beginning of learning (A) & $64,19 \%$ & \\
& Learning process (B) & $66,78 \%$ & \\
& End of learning (C) & $71,94 \%$ & \\
& $\bar{X}$ & $67,64 \%$ & Moderate \\
\cline { 2 - 3 } 2 & Beginning of learning (A) & $73,60 \%$ & \\
& Learning process (B) & $77,04 \%$ & \\
& End of learning (C) & $79,08 \%$ & \multirow{2}{*}{ Good } \\
& $\bar{X}$ & $76,57 \%$ & \\
\cline { 2 - 3 } 3 & Beginning of learning (A) & $79,83 \%$ & \\
& Learning process (B) & $80,27 \%$ & Good \\
& End of learning (C) & $82,51 \%$ & \\
& $\bar{X}$ & $80,87 \%$ & \\
\hline
\end{tabular}

Source: Research Data for 2020

Based on the data in Table 1., it can be explained as follows: (1) The first learning that was carried out on Monday 30 March 2020 obtained data that: component A with an average percentage of learning was $64.19 \%$, component B with an average percentage of learning was $66.78 \%$, and component $\mathrm{C}$ with an average the average percentage of learning is $71.94 \%$. As a percentage of the final average in the first learning is $67.64 \%$, which later in this study belongs to the moderate category; (2) The second learning that was carried out on Monday, April 6, 2020, obtained data that: component A with an average percentage of learning was $73.60 \%$, component B with an average percentage of learning was $77.04 \%$, and component $\mathrm{C}$ with an average the average percentage of learning is $79.08 \%$. As a percentage of the final average in the first learning is $76.57 \%$, which then in this study is included in the good category; and (3) The third learning that was carried out on Monday, April 13, 2020, obtained data that: component A with an average percentage of learning was $79.83 \%$, component B with an average percentage of learning was $80.27 \%$, and component $\mathrm{C}$ with an average the average percentage of learning is $82.51 \%$. As a percentage of the final average in the first learning is $80.87 \%$, which then in this study is included in the good category. 
After the presentation of research data, further discussion of the discussion can be described as below:

First, relating to formative class evaluation data, when discussing learning carried out by teachers inside and outside the classroom that will have more meaningfulness if it involves students actively. The teacher acts as a facilitator and puts himself as a pleasant friend, therefore how students feel in carrying out the learning process also needs to be expressed. Formative class evaluation is a questionnaire given to students that aims to find out what level of student acceptance in learning. As explained in the results of the research that has been carried out obtained data from students' questionnaire inputted by https://forms.office.com/ as follows: (1) The average data range of scores in the first learning is 2.37 which means included in the moderate category; (2) The average data range of scores in the first learning is 2.59 which means it is included in the good category; and (3) The average data range of scores in the first learning is 2.67 which means it is included in the good category. The results of this study have links with research that has been conducted by several researchers, namely: (1) Self-motivation, quality and service of teacher learning, and the effects of peers have a positive and significant impact on student learning outcomes[11] ${ }^{11}$; (2) Students who get attention and good facilities have high learning motivation and have an impact on learning outcomes in class; and (3) There is a significant relationship between learning motivation with students' interest in learning in elementary school[12] ${ }^{12}$. Learning is an interaction pattern of the acquisition process of habits, knowledge, and attitudes that change behavior related to character, physical, and psychological. Learning is influenced by two factors: internal and external. Then, with the support of these factors students have high achievement this means that the person has good knowledge of theories and concepts as well as an impact on behavior and attitude changes. Thus the consequences of an education is aimed at making a change from pessimistic attitude to optimism, people who when initially unable to do something become people who are able to even improve their achievements. This can be done by a teacher how they can provide motivation to be able to improve their learning achievement. Support in the learning process is carried out by presenting digital learning through the zoom application, researchers and teachers then provide animated learning shows about clean air for health, the way the body processes clean air and the impact of unclean air. It also displayed a video on how the benefits of clean air and how to maintain healthy lung health. Additional material was also provided, namely the danger of free air and the spread of the Covid-19 virus, how to wear masks and the health benefits of hand washing. Means and media that are interesting according to the contents of today's content become very interesting in the direction of the normal era of new life. Digital has evolved and become the foundation of learning interactions, then to achieve high learning outcomes required traits and behaviors such as: high aspirations, actively working on assignments, high trust, good interaction, readiness to learn and so on. The nature and characteristics required in the learning activities are only found in individuals who have high motivation, while 
those who have low motivation do not exist so that it will hamper their learning activities.

Second, related to learning process and product data can be understood, namely teaching and learning activities are closely related to learning strategies, researchers use the zoom and WA applications that become more familiar in the middle of social distancing and physical distancing as it is today. The learning process is reflected in the results of the learning process and product which includes three components, namely: (1) Beginning of learning (A); (2) The process or core of learning (B); and (3) End of learning (C). Furthermore, these three components are averaged on the results to determine the level of success of the learning process. The learning outcomes data that have been carried out in this study are as follows: (1) The average learning data from the first component $\mathrm{A}+\mathrm{B}+\mathrm{C}$ is $67.64 \%$ which means moderate; (2) The second learning average data from components $A+B+C$ is $76.57 \%$ which means good; (3) The average learning data of the three components of $\mathrm{A}+\mathrm{B}+\mathrm{C}$ is $80.87 \%$ which means good. Graphically the data of each lesson has increased in percentage, this shows the success of the application of the media used. This research has links with several previous studies, including: (1) Science learning has increased learning outcomes, teachers develop IT-based multimedia learning[13 $]^{13}$; (2) Development of interactive learning module (ILM) based on multimedia-mediated studentcentered learning environment (MMSLE) can increase motivation to learn in class; and (3) The ways of innovative learning methods with intense teacher and student interactions, provide the closeness of learning $[14]^{14}$. Literally, the teaching and learning process is the interaction of reciprocal communication between the instructor as the source of the message and the recipient of information, namely students through media channels. Utilization of learning resources in the form of attractive digital learning media, can make the process of communication through distance learning take place more effectively and efficiently. The success of delivering a good message from the teacher, can stimulate the thoughts, feelings, interests, and attention of students, then in turn teaching and learning interactions can take place. Digital media can play a role as a tool that has the role of: (1) Tools for introducing information, in this case clean air material for health and the Covid-19 outbreak; (2) Providing new and enjoyable experiences for teachers and students; (3) Tools for increasing knowledge and skills in learning; (4) Growing students' interest and motivation to learn because learning is more interesting; and (5) Being able to help shape students' mental models. Therefore, the role and task of the teacher can then be shifted from the main learning resource to a learning resource manager.

\section{Conclusion}

Based on the background of the problem, the results of the study and discussion in this study, the following conclusions can be drawn as follows: (1) Formative class 
evaluation data show that students' interest and motivation towards digital learning carried out is above the average of moderate, this gives an understanding if digitalbased learning is accepted and understood by students; and (2) The results of learning process data and product graphically data from each learning experience increases in percentage, this shows the success of the application of digital-based media used.

\section{Suggestion}

Recommendations that can be given from the results of this research study are: (1) Teachers in the midst of this pandemic have more time to prepare teaching materials that were originally using manual guidance that can be transferred with digital media; (2) Parents are able to give more time to be with students at home, and parenting education is becoming increasingly necessary after this pandemic outbreak; (3) This research has only been carried out in a limited scope, research is needed with a wider scope and developments in digital media that are easily applied by teachers and students.

\section{References}

[1] Mudana IGAMG. Membangun karakter dalam perspektif filsafat pendidikan Ki Hadjar Dewantara. J Filsafat Indones 2019;2:75.

[2] Prastowo A. Transformasi kurikulum pendidikan dasar dan menengah di Indonesia. JIP J Ilm PGMI 1970;4:111-25.

[3] Ulfa Hidayah , Ida Bagus Putrayasa INM. Konsistensi kompetensi inti (KI), kompetensi dasar (KD), dan indikator pada evaluasi guru dalam pembelajaran eksposisi berdasarkan kurikulum 2013 siswa kelas X MAN Patas. Pendidik Bhs Dan Sastra Indones Univ Pendidik Ganesha Jur Pendidik Bhs Dan Sastra Indones 2016;5.

[4] Yuliana. Corona virus diseases (Covid -19); sebuah tinjauan literatur. Wellness Heal. Mag., vol. 2, Sello Editorial Javeriano; 2020, p. 187-92.

[5] Purwanto A, Pramono R, Asbari M, Santoso PB, Wijayanti LM, Choi CH, et al. Studi eksploratif dampak pandemi COVID-19 terhadap proses pembelajaran online di sekolah dasar. EduPsyCouns J Educ Psychol Couns 2020;2:1-12.

[6] Setiawan AR. Lembar kegiatan literasi saintifik untuk pembelajaran jarak Jauh topik penyakit Coronavirus 2019 (COVID-19). J Edukatif 2020;2:28-37.

[7] Kumari S, Mittal R. WhatsApp: A worth medium of communication for transfer of technology to the masses. Curr J Appl Sci Technol 2017;23:1-9.

[8] Safitri I, Pasaribu R, Simamora SS, Lubis K. The effectiveness of android application as a student aid tool in understanding physics project assignments. J Pendidik IPA Indones 2019;8:512-20.

[9] Wildan W. Pelaksanaan penilaian autentik aspek pengetahuan, sikap dan keterampilan di sekolah atau madrasah. J Tatsqif 2017;15:131-53.

[10] Nurpratiwi, R. S., Sriwanto, S., Sarjanti E. Peningkatan aktivitas dan prestasi belajar siswa melalui metode picture and picture dengan media audio visual pada mata pelajaran geografi di kelas XI IPS 2 SMA Negeri 1 Bantarkawung. Geo Edukasi 2015;4:1-9.

[11] Lee I. The effect of learning motivation, total quality teaching and peer-assisted learning on study achievement: empirical analysis from vocational universities or colleges ' students in Taiwan. Adult Learn 2010;6:56-74. 
[12] Fauziah A, Rosnaningsih A, Azhar S. Hubungan antara motivasi belajar dengan minat belajar siswa kelas IV SDN Poris Gaga 05 Kota Tangerang. J JPSD (Jurnal Pendidik Sekol Dasar) 2017;4:47.

[13] Akhlis, I. Dewi N. Pengembangan media pembelajaran IPA Terpadu Berkarakter Peduli Lingkungan Tema "Konservasi" Berpendekatan Science-Edutainment. J Pendidik IPA Indones 2013;2:203-8.

[14] Almarabeh H, Amer EF, Sulieman A. The effectiveness of multimedia learning tools in education. Int J Adv Res Comput Sci Softw Eng 2015;5:761-4. 